\title{
Estimation of influence of heat-conducting inclusions on thermal protection of filler constructions of buildings
}

\author{
Andrew Kiselman, Denis Portnyagin*, Ekaterina Ibe and Galina Shibaeva \\ Khakass Technical Institute, Siberian Federal University, Department of Building, transport and \\ mechanical engineering, 655017, Abakan, Khakasia, Russia
}

\begin{abstract}
Article represents recommendations on decrease in heat losses through heat-conducting inclusions of filler constructions of buildings. Recommendations are based on the analysis of calculations by a finite element method in software package Elcut. The purpose consists in the analysis of expediency of replacement of a steel reinforcement on glass composite reinforcement in design decisions of filler constructions in view of calculation of thermal fields. The way of decrease in the factor of cold bridges is researched by replacement of a steel reinforcement by glass composite reinforcement. It is analysed constructive units: fastenings of facing verst to a diaphragm of rigidity; adjunctions of an external wall to a column. On a result efficiency of replacement of a steel reinforcement on glass composite reinforcement in filler constructions of walls is revealed, and also results of calculation of thermal losses of design decisions of filler constructions of a building are resulted.
\end{abstract}

\section{Introduction}

Maintenance of reliability, durability and energy efficiency of filler constructions of residential buildings - a problem demanding the complex decision. Filler constructions of modern buildings can contain inside of themselves various elements at which heat conductivity is much more than heat conductivity of the basic layers. These elements, socalled heat-conducting inclusions, are the reason of occurrence of the additional heat flows which are passing through them. Additional heat flows lead to increase in heat losses and decrease in a level of a heat-shielding of a building [5, 9].

The energy efficient construction every year gets the increasing urgency and promptly develops [11]. There are the new buildings constructed on modern technologies with increased requirements to a heat-shielding and improved characteristics of an energy consumption $[8,13]$. Realization of these conditions it is impossible without the analysis of processes of carry of heat through filler constructions [12], and also without use of modern materials, including - glass composite [6, 10].

The mechanical and technological properties of a steel reinforcement accepted under operating normative documents, are sufficient for the decision of the majority of problems. However there is a certain list of problems in which the proved alternative is the glass

\footnotetext{
* Corresponding author: $\underline{\text { my4455@ @andex.ru }}$
} 
composite reinforcement, being less heat conductive, and also possessing high corrosion stability.

As potential cold bridges in a masonry wall lines with a steel reinforcement are marked. So, in article $[6,10]$ as a variant of increase of thermal efficiency of a filler construction replacement of a steel reinforcement by glass composite reinforcement is offered, that somewhat raises heat-shielding properties of a filler construction.

Formal warming of filler constructions it is impossible to achieve significant reduction of heat losses as their essential share is necessary on cold bridges, that is sites of intensive heat exchange with an environment.

The important problem is determination of heat-shielding qualities of filler constructions $[4,7]$. The decision of this problem allows to estimate conformity of building structures to normative requirements, and also to determine real losses of heat, to develop measures on increase of thermal protection of buildings. Authors [1-3] researched this problem, however for maintenance of an energy efficiency and durability of a filler construction it is required to analyse an opportunity of formation of cold bridges and to develop recommendations on their elimination.

The purpose of research is increase of a heat-shielding and durability of units of filler constructions of buildings with replacement of a steel reinforcement by a glass composite material in an external brick wall.

\section{Methods}

A study of the thermal insulation of building envelops consists of three parts. The first part is a visual inspection with Thermal imaging FlirB200 to find cracks, structural defects, the heatlosses places and mold places.

The second part is a computation of structural sites using the soft package Elcut and SCAD Office to study the thermal field of the external wall and certain deformations of the facing layer of brick and comparison of results depending on the type of insulation.

The third part consists in the study of the properties of mineral wool insulation, depending on its humidity.

Mathematical modeling of the thermal regime of the structure in the cold season was carried out under the following boundary conditions:

inside air temperature in the building tint $=20{ }^{\circ} \mathrm{C}$ (Russian standard GOST 304942011);

outside air temperature text $=-37^{\circ} \mathrm{C}$ (Russian construction norm SP 50.13330.2012);

heat transfer coefficient at the internal surface of the envelope $\alpha s i=8.7 \mathrm{~W} /\left(\mathrm{m}^{2 \circ} \mathrm{C}\right)$ (Russian construction norm SP 50.13330.2012);

heat transfer coefficient at the external surface of the envelope $\alpha$ se $=23 \mathrm{~W} /\left(\mathrm{m}^{2 \circ} \mathrm{C}\right)$ (Russian construction norm SP 50.13330.2012)

\section{Results}

As objects for the study are use apartment building in Abakan, built with the multi-layered masonry (tab. 1, 2). The house were built in 2018.

For the analysis of an energy efficiency from use of a kind of a material of reinforcement for a filler construction units (tab. 1,2) are chosen:

1) A constructive unit of fastening of facing verst to a diaphragm of rigidity;

2) A constructive unit of an adjunction of an external wall to a column.

Thermal ratings through a heat-conducting inclusion it is determined by means of calculation of temperature fields in software package Elcut. 
Settlement characteristics of materials of a structure of a wall are resulted in table 2 . Boundary conditions for a of Abakan of republic Khakassia are set:

1) Temperatures internal and air: $\mathrm{T}_{\mathrm{i}}=20^{\circ} \mathrm{C}$ and $\mathrm{T}_{\mathrm{e}}=-37^{\circ} \mathrm{C}$;

2) Factors of a heat transfer of an internal and external surface of filler constructions, accordingly: 8.7 and $23 \mathrm{~W} / \mathrm{m}^{2}{ }^{\circ} \mathrm{C}$.

In table 1 the temperature fields of constructive units executed with use of steel and glass composite reinforcement are presented.

Table 1. The analysis of an energy efficiency of design decisions. Constructive unit 1: Fastening of facing verst to a diaphragm of rigidity

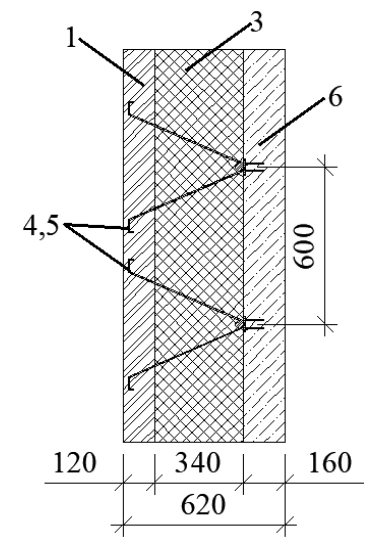

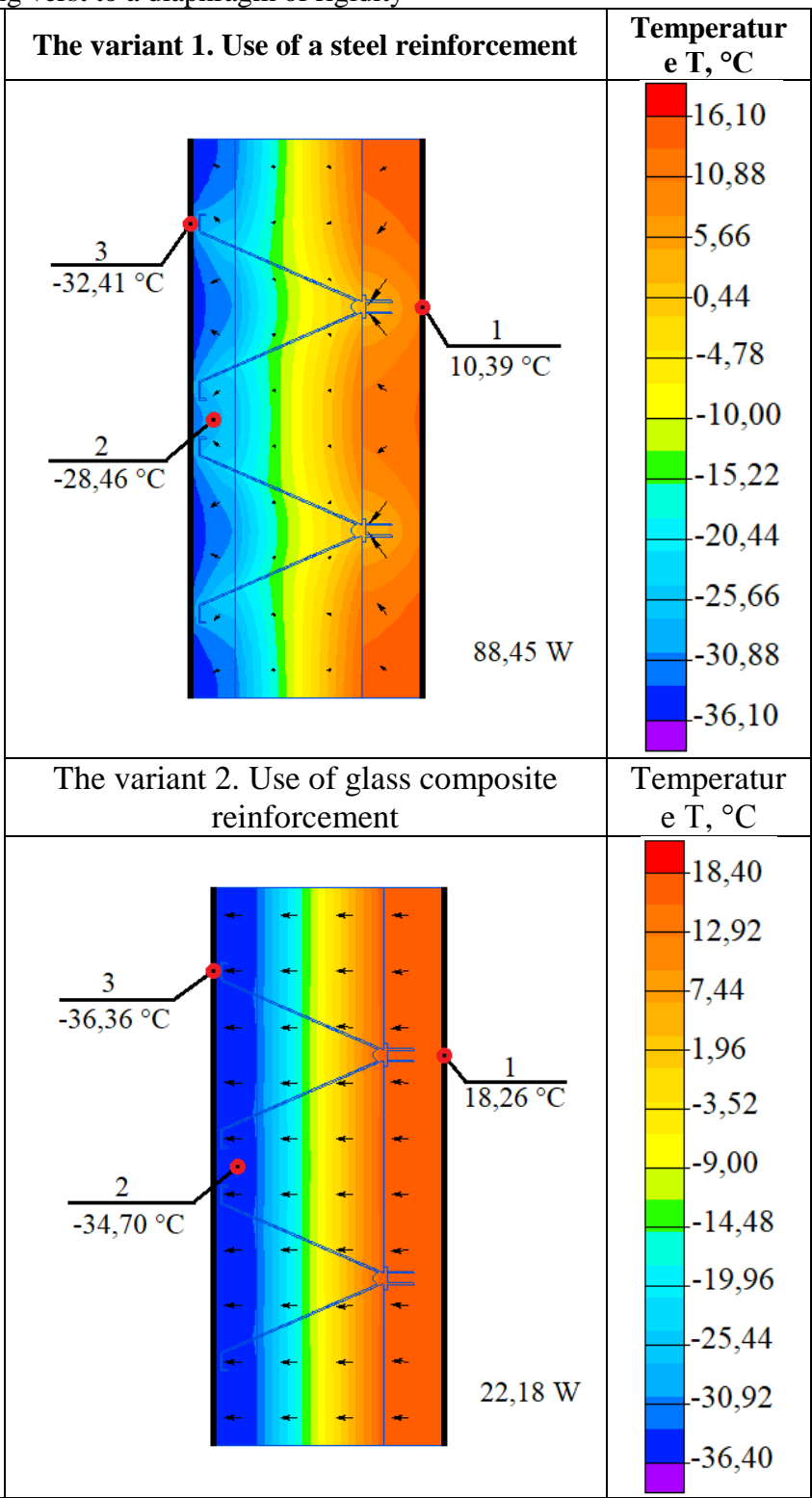


Table 2. The analysis of an energy efficiency of design decisions. Constructive unit 2: Adjunction of an external wall to a column

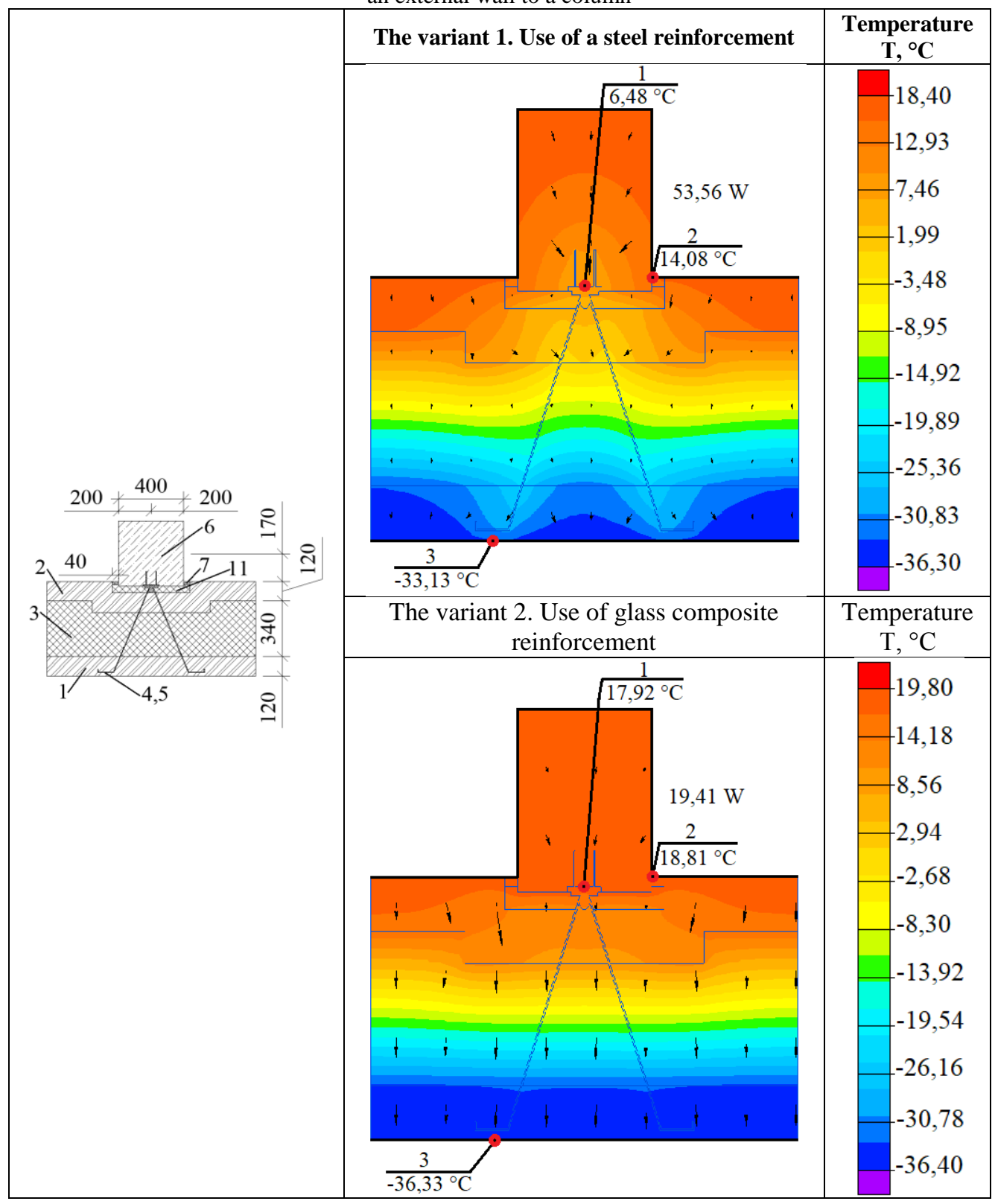

Table 3. Characteristics of materials of a filler construction

\begin{tabular}{|l|l|c|c|}
\hline $\begin{array}{c}\text { Item } \\
\text { number* }\end{array}$ & \multicolumn{1}{|c|}{ Material } & $\begin{array}{c}\text { Density } \\
\text { material, } \mathrm{kg} / \mathrm{m}^{3}\end{array}$ & $\begin{array}{l}\text { Factor of heat } \\
\text { conductivity. } \mathrm{Wt} /\left(\mathrm{m} \cdot{ }^{\circ} \mathrm{C}\right)\end{array}$ \\
\hline 1 & $\begin{array}{l}\text { Brick hollow ceramic on a } \\
\text { cement mortal-sandy }\end{array}$ & 1600 & 0.58 \\
\hline 2 & $\begin{array}{l}\text { Brick ceramic on a cement } \\
\text { mortal-sandy }\end{array}$ & 1800 & 0.70 \\
\hline 3 & Polystyrene foam concrete & 300 & 0.095 \\
\hline
\end{tabular}




\begin{tabular}{|c|l|c|c|}
\hline 4 & Steel reinforcement & 7850 & 58 \\
\hline 5 & $\begin{array}{l}\text { Glass composite } \\
\text { reinforcement }\end{array}$ & 1.90 & 0.48 \\
\hline 6 & Ferro-concrete & 2500 & 1.92 \\
\hline 7 & Cement mortal-sandy & 1800 & 0.76 \\
\hline 8 & Mastic & 100 & 0.032 \\
\hline 9 & Assembly foam & $25-35$ & 0.033 \\
\hline 10 & Vilaterm & $25-50$ & 0.035 \\
\hline 11 & Mineral wool board P-75 & $57-83$ & 0.037 \\
\hline
\end{tabular}

* Item number to look together with tables 1,3 .

\section{Discussions}

The two solutions of the material of reinforcement are presented. Calculations were done through the standard soft package Elcut, using an approximation of the Laplace equation by the finite element method ( table 4, 5).

Table 4. The analysis of an energy efficiency of design decisions (The rest of the table 1)

\begin{tabular}{|c|c|c|c|}
\hline Item number & $\begin{array}{c}\text { The variant 1. Use of } \\
\text { a steel reinforcement }\end{array}$ & $\begin{array}{c}\text { The variant 2. Use of } \\
\text { glass composite } \\
\text { reinforcement }\end{array}$ & $\begin{array}{c}\text { Difference of values } \\
\text { of temperature, }{ }^{\circ} \mathbf{C}\end{array}$ \\
\hline 1 & 10.39 & 18.26 & 7.87 \\
\hline 2 & -28.46 & -34.70 & 6.24 \\
\hline 3 & -32.41 & -36.36 & 3.95 \\
\hline
\end{tabular}

Table 5. The analysis of an energy efficiency of design decisions (The rest of the table 3)

\begin{tabular}{|c|c|c|c|}
\hline Item number & $\begin{array}{c}\text { The variant 1. Use } \\
\text { of a steel } \\
\text { reinforcement }\end{array}$ & $\begin{array}{c}\text { The variant 2. Use } \\
\text { of glass composite } \\
\text { reinforcement }\end{array}$ & $\begin{array}{c}\text { Difference of values } \\
\text { of temperature, }{ }^{\circ} \mathrm{C}\end{array}$ \\
\hline 1 & 6.48 & 17.92 & 11.44 \\
\hline 2 & 14.08 & 18.81 & 4.73 \\
\hline 3 & -33.13 & 36.33 & 3.20 \\
\hline
\end{tabular}

The analysis of use of glass composite reinforcement (unit 1) it is visible, that the heat flow on an internal and external contour decreases in comparison with a variant from steel on $74.92 \%$ and $75.00 \%$, accordingly. Also rise in temperature of a surface of a wall till $18.26{ }^{\circ} \mathrm{C}$ (instead of $10.39{ }^{\circ} \mathrm{C}$ ) is marked. Thus the temperature of a surface on an internal and external contour is distributed more homogeneously.

At use of glass composite reinforcement (unit 2) the heat flow on an internal and external contour decreases in comparison with a variant from steel on $63.76 \%$ and 63.75 $\%$, accordingly. Also rise in temperature of a surface of a wall till $18.81{ }^{\circ} \mathrm{C}$ (instead of $14.08^{\circ} \mathrm{C}$ ) is observed.

On the basis of the above-stated from the point of view of an energy efficiency the most rational variant of use of a material of reinforcement in a masonry is the glass composite reinforcement which allows to lower heat losses of a room through constructive units in their local places in some times. The thermal comfort of a room also improves. 


\section{Conclusions}

Thus, the analysis of thermal fields of filler constructions has shown, that at replacement of traditionally used steel reinforcement on glass composite during designing thermal losses decrease. In considered constructive units in local places decrease in thermal losses makes up to $50 \%$ and more only due to minimization of cold bridges, that evidently shows software package Elcut.

The analysis of the received results testifies that offered design decisions allow to provide conditions of comfortable residing and stay of people in buildings. The rational choice of a kind of a material in a bricklaying of filler constructions not only reduces heat losses, but also raises thermal comfort of rooms of residential buildings.

\section{References}

1. G. Barrios, G. Huelsz, R. Rechtman, J. Rojas, Energy and Buildings. 1(43), 219-223 (2011)

2. W. Maref, N. Van Den Bossche, M. Armstrong, M. A. Lacasse, H. Elmahdy, Glazer R., Journal of Building Physics. 36, 35-56 (2012)

3. F. Miranville, A. H. Fakra, S. Gnichard, H. Boyer, P. Praene, D. Bigot, Energy and Buildings. 48, 79-90 (2012)

4. T. Thorsell, M. Bomberg, Journal of Building Physics. 35, 83-96 (2011)

5. G. M. Bad'in, S. A. Sychev, N. A.Pavlova, Molodoj uchyonyj. 8, 1268 - 1271 (2016)

6. A. T. Bekker, A. M. Umanskij, Vologdinskie chteniya, 23-25 (2012)

7. E. I. Vakunin, Izvestiya Tul'skogo gosudarstvennogo universiteta. Nauki o zemle. 41-46 (2011)

8. V. G. Gagarin, V. V. Kozlov, S. I. Kryshov, O. I. Ponomarev, AVOK. 5, 46-60 (2009)

9. V. G. Gagarin, V. V. Kozlov, Academia. Arhitektura i stroitel'stvo. 3, 279 - 286 (2010)

10. E. V. Goleva, M. V. Gurova, YU. V. Panyukova, V. M. Kretova, XI Studencheskaya mezhdunarodnaya zaochnaya nauchno-prakticheskaya konferenciya «Molodezhnyj nauchnyj forum: tekhnicheskie i matematicheskie nauki». 4, 55-60 (2014)

11. A. S. Gorshkov, V. I. Livchak, Stroitel'stvo unikal'nyh zdanij i sooruzhenij. 3(30), 7-37 (2015)

12. D. D. Zaborova, M. I. Kukolev, T. A. Musorina, M. R. Petrichenko, Nauchnotekhnicheskie vedomosti Cankt-Peterburgskogo gosudarstvennogo politekhnicheskogo universiteta. 4(254), 28 - 33 (2016)

13. M. M. Rybakov, Internet-zhurnal Naukovedenie. 1-13 (2016) 